\title{
Interactive social media interventions to promote health equity: an overview of reviews
}

\author{
V. Welch, PhD (1); J. Petkovic, MSc (2); J. Pardo Pardo, BSc (2); T. Rader, MLIS (3); P. Tugiwell, MD (1, 3, 4)
}

This article is part of our Health Equity Series.

Tweet this article

This article has been peer reviewed.

\begin{abstract}
Introduction: Social media use has been increasing in public health and health promotion because it can remove geographic and physical access barriers. However, these interventions also have the potential to increase health inequities for people who do not have access to or do not use social media. In this paper, we aim to assess the effects of interactive social media interventions on health outcomes, behaviour change and health equity.
\end{abstract}

Methods: We conducted a rapid response overview of systematic reviews. We used a sensitive search strategy to identify systematic reviews and included those that focussed on interventions allowing two-way interaction such as discussion forums, social networks (e.g. Facebook and Twitter), blogging, applications linked to online communities and media sharing.

Results: Eleven systematic reviews met our inclusion criteria. Most interventions addressed by the reviews included online discussion boards or similar strategies, either as stand-alone interventions or in combination with other interventions. Seven reviews reported mixed effects on health outcomes and healthy behaviours. We did not find disaggregated analyses across characteristics associated with disadvantage, such as lower socioeconomic status or age. However, some targeted studies reported that social media interventions were effective in specific populations in terms of age, socioeconomic status, ethnicities and place of residence. Four reviews reported qualitative benefits such as satisfaction, finding information and improved social support.

Conclusion: Social media interventions were effective in certain populations at risk for disadvantage (youth, older adults, low socioeconomic status, rural), which indicates that these interventions may be effective for promoting health equity. However, confirmation of effectiveness would require further study. Several reviews raised the issue of acceptability of social media interventions. Only four studies reported on the level of intervention use and all of these reported low use. More research on established social media platforms with existing social networks is needed, particularly in populations at risk for disadvantage, to assess effects on health outcomes and health equity.

Keywords: social media, disadvantaged populations, public health, health promotion, health equity

\section{Introduction}

Social media is increasingly used for public health and health promotion: $60 \%$ of state departments in the United States use one or more social media applications; ${ }^{1}$ the Public Health Agency of Canada has a presenceon social media sites including Twitter
Highlights

- The use of social media interventions has been increasing in the field of public health as they can cross geographical and physical access barriers.

- Eleven systematic reviews found mixed effects of social media interventions on improving health outcomes and healthy behaviours.

- Some of the reviewed studies found benefits from social media interventions while others found no change or found that outcomes were worse than those from non-social media interventions.

- We know little about how the design and implementation features and the intensity and duration of interventions could improve health or whether they could increase negative behaviours, stigmatization or exacerbation of health inequities.

- Many of the studies used social media platforms that were developed by the researchers. The effects of using existing social networks with commercial platforms, such as Facebook and Twitter, as part of social media health interventions are unknown.

(2300 tweets, over 52000 followers as of January 14, 2015) ${ }^{2}$ and Facebook (over 13 000 "likes" as of January 14, 2016) ${ }^{3}$; and 34 out of the 36 public health units in Ontario ${ }^{4}$ are using social media. Social media holds promise for public health interventions reaching a wide number of people as over $60 \%$ of adults and $90 \%$ of youth with Internet access in Canada are active on one or more forms of social media. ${ }^{5,6}$

Author references:

1. Bruyère Research Institute, University of Ottawa, Ottawa, Ontario, Canada

2. Centre for Global Health, University of Ottawa, Ottawa, Ontario, Canada

3. Ottawa Hospital Research Institute, University of Ottawa, Ottawa, Ontario, Canada

4. Department of Medicine, Faculty of Medicine, University of Ottawa, Ontario, Ottawa, Canada

Correspondence: Vivian Welch, 43 Bruyère Street, Annex E room 304, Ottawa, ON K1N 5C8; Tel: 613-562-6262 ext. 2904; Fax: 613-569-6734; Email: Vivian.Welch@uottawa.ca 
Various social media can be defined by the extent to which they focus on seven functional building blocks to do with the degree of interaction and communication among users: 1) identity: the extent to which users reveal themselves; 2) conversations: the extent to which users communicate with each other; 3) sharing: the extent to which users exchange, distribute and receive content; 4) presence: the extent to which users know if others are available; 5) relationships: the extent to which users relate to each other; 6) reputation: the extent to which users know the social standing of others and content; and 7) groups: the extent to which users form communities. ${ }^{7}$

Evidence from systematic reviews suggests social media that facilitates interaction with other users by way of bulletin boards, chatrooms or available networking sites (e.g. Twitter and Facebook) effectively improves knowledge. However, effects on health behaviours (e.g. smoking, eating, physical activity) and health outcomes (such as weight loss and mental health) have been found to be both positive and negative. ${ }^{8-12}$ While the social media interventions in these reviews were mostly assessed in well-educated, higher-income populations, some studies have shown benefits for low-income populations, older adults, youth and different ethnocultural groups.

However, mass media strategies for public health also have the potential to increase health inequities, defined as differences in health outcomes that are avoidable and unfair. ${ }^{13,14}$ Differences in access to technology and cultural differences and preferences might affect uptake and use of social media interventions and may also result in health inequities.

In this paper, we aim to assess the effects of interactive social media interventions for health communication on health outcomes, behaviour change and health equity by overviewing systematic reviews.

\section{Methods}

\section{Approach}

We defined the review question using the population, intervention, comparator, outcome (PICO) approach. ${ }^{15}$

\section{Population}

We included systematic reviews of any population exposed to a social media intervention.

\section{Intervention}

We defined social media as "activities among people gathered online who share information using conversational media that make it easy to create and share content in the form of words, pictures, videos, and audios." ${ }^{, 16}$ As mentioned previously, different types of social media can be defined by the extent to which they focus on seven functional building blocks. ${ }^{7}$ Social media includes activities such as discussion forums, social networks (e.g. Facebook and Twitter), blogging and microblogging, bookmarking and media sharing. ${ }^{17}$ To distinguish from other web-delivered programs and to qualify as social media for the purposes of this review, an intervention needed to have an interactive component with two-way communication between peers or between the website and users.

We excluded mass media and any unidirectional forms of health communication (e.g. where the Internet or text messages are used to broadcast messages with no interactive component). We also excluded e-health interventions that involved using technology to deliver health care (e.g. using remote consultation between a patient and a provider through the Telestroke network). ${ }^{18,19}$ We excluded smartphone applications if they lacked an interactive component with other users (e.g. feedback or tracking of weight on a smartphone for personal use only with no sharing or feedback from other users/peers).

\section{Comparator}

We included comparators of usual care, no intervention, or another intervention method that may have had a social media component. Usual care could include any type of health care or health promotion activity. We kept the comparator broad so we could compare this to any other method of delivering health promotion or health care for the same condition.

\section{Outcomes}

We included systematic reviews that reported on at least one of the following primary outcomes: physical outcomes (e.g. weight change, functional status), psychosocial health outcomes (e.g. quality of life and self-efficacy), satisfaction, behaviour change and adverse effects (e.g. addiction, depression). We collected and reported data on secondary outcomes of attitudes and knowledge. We documented process measures such as quality of communication, knowledge, reach, engagement and fidelity of the intervention (whether the intervention was implemented as planned). ${ }^{20}$

To assess the outcome of health equity, we determined whether results were presented separately across characteristics associated with privilege/disadvantage. We also assessed whether the intervention was aimed at a disadvantaged population, which could potentially improve health equity. We used the acronym PROGRESS-Plus to identify these characteristics, defined as Place of residence, Race/ethnicity/culture/language, Occupation, Gender/sex, Religion, Education, Socioeconomic status, Social capital or other factors associated with privilege/disadvantage such as age (e.g. children or elderly), sexual orientation, and disease status. ${ }^{21}$

\section{Study design}

We conducted a rapid response overview of systematic reviews approach. A rapid response provides an overview of the available evidence, usually from guidelines or systematic reviews, in response to a need or priority identified by a knowledge user in a short timeframe. $^{22,23}$ An a priori protocol was developed and submitted to the Public Health Agency of Canada as a Statement of Work (available from the authors on request). We defined a systematic review as a systematic and transparent synthesis of eligible studies, with transparent methods and an explicit search strategy. We included reviews of randomized controlled trials, nonrandomized studies and qualitative studies.

\section{Search methods for identification of studies}

We designed a sensitive search strategy to retrieve systematic reviews from electronic bibliographic databases. Our knowledge user advised us to avoid a grey literature search because of time constraints. To retrieve systematic reviews, we used the Montori filter, a validated systematic review 
study design filter. ${ }^{24}$ No date limitations or language restrictions were applied.

We identified 4580 items from the following databases on 27 February 2014:

- MEDLINE via OVID $\left(1946^{*}\right.$ to 27 February 2014);

- PsycINFO via OVID (PsycINFO 1806 to February Week 3 2014);

- Cochrane Library via Wiley (Issue 2 of $12,2014)$ including the Cochrane Database of Abstracts of Reviews of Effects (DARE), Cochrane Database of Systematic Reviews (CDSR), Health Technology Assessment (HTA) and Economic Evaluations Database (EED) to scan the reference lists of relevant systematic reviews;

- PUBMED via National Library of Medicine "Related Articles" search in PUBMED using 4 relevant systematic reviews as seed papers, 27 February 2014; and

- Campbell Library (hand searched all issues, 2004-present).

The search strategy was devised in OVID MEDLINE by a librarian scientist (TR) and peer reviewed by another member of the team (JPP) following PRESS (Peer Review of Electronic Search Strategies) guidelines. ${ }^{25}$ The strategy was then adapted for the other databases. The complete search strategies are available upon request.

All databases were searched from inception to 27 February 2014. Duplicates were removed electronically using EndNote, leaving 4102 citations.

\section{Inclusion criteria}

We included reviews if they assessed the effects of social media health promotion interventions (description of eligible social media interventions described in Table 1) on health behaviour or health outcomes.

\section{Data extraction}

We extracted data on the following:

- intervention description;

- comparator;

- outcomes;

- review exclusion criteria;

- number of included studies;
- number of participants in intervention and control groups (enrolled and completed);

- country setting;

- population description including median age and percentage of females;

- description of population, analysis or interpretation by PROGRESS-Plus;

- outcome - summary and quantitative pooled result (if available);

- usage of social media (how much participants used the intervention), reach of the intervention and activities to increase engagement of the participants with the intervention (e.g. use of a moderator);

- confounders;

- adverse effects;

- risk of bias;

- applicability for PROGRESS-Plus populations discussed; and

- AMSTAR score.

\section{Quality assessment of reviews}

We used the AMSTAR tool (http://amstar. ca/Amstar_Checklist.php) to assess the quality of the systematic reviews. ${ }^{26} \mathrm{We}$ considered systematic reviews to be of high quality when they addressed all 11 items on the AMSTAR checklist.

TABLE 1

Definition of social media interventions

\begin{tabular}{|c|c|c|}
\hline Social media format & Included & Excluded \\
\hline Blogs and microblogs (e.g. Twitter) & If the intervention includes multi-way interaction & $\begin{array}{l}\text { One-way messages and posts or direct contact with a health care } \\
\text { provider }\end{array}$ \\
\hline $\begin{array}{l}\text { Content communities } \\
\text { (e.g. YouTube, Pinterest) }\end{array}$ & If the intervention includes multi-way interaction & $\begin{array}{l}\text { One-way messages and posts or direct contact with a health care } \\
\text { provider }\end{array}$ \\
\hline $\begin{array}{l}\text { Discussion groups (e.g. chat } \\
\text { rooms, online bulletin boards, } \\
\text { discussion forums) }\end{array}$ & $\begin{array}{l}\text { Synchronous or asynchronous discussion groups or } \\
\text { boards }\end{array}$ & $\begin{array}{l}\text { One-way messages and posts or direct contact with a health care } \\
\text { provider }\end{array}$ \\
\hline Emails & $\begin{array}{l}\text { List servs that allow for communication, discussion } \\
\text { and visible record of the discussion for others to view } \\
\text { and comment }\end{array}$ & One-way emails (e.g. reminders) \\
\hline Mobile applications (apps) & $\begin{array}{l}\text { Apps that allow for communication and interaction } \\
\text { with a group of people }\end{array}$ & $\begin{array}{l}\text { Apps that allow a person to track and monitor their progress (e.g. weight } \\
\text { loss, blood sugar, etc.) without a social component or apps used to } \\
\text { communicate with a health care provider }\end{array}$ \\
\hline SMS/text messages & If the messages remain posted for others to view & $\begin{array}{l}\text { One-way text messages (e.g. reminders) or text messages with reply and/ } \\
\text { or feedback from health care provider/researchers }\end{array}$ \\
\hline Virtual gaming worlds & $\begin{array}{l}\text { If there is communication between multiple players } \\
\text { (and there is a health outcome) }\end{array}$ & Online games without social and health components \\
\hline $\begin{array}{l}\text { Virtual social networks } \\
\text { (e.g. Facebook) }\end{array}$ & If the intervention includes multi-way interaction & $\begin{array}{l}\text { One-way messages and posts or direct contact with a health care } \\
\text { provider }\end{array}$ \\
\hline Webpages and Wikis & If the website/Wiki allows for multi-way interaction & One-way communication (e.g. education) \\
\hline
\end{tabular}

"Since there is no definitive date when social media phenomenon began, we chose not to apply a date limit. Instead, we focussed on search terms that describe the social media intervention and retrieved relevant material regardless of the date of publication. 


\section{Synthesis methods}

The interventions and populations were too heterogeneous to pool results. We narratively summarized effects on participant-important outcomes for each type of intervention as well as process outcomes, including the fidelity of the intervention and reach and level of engagement (if measured) using effect sizes (if reported). We checked the extent to which the primary studies in the eligible systematic reviews were overlapping. Dichotomous outcomes are presented as relative risks, and continuous outcomes as weighted mean differences. We report the pooled results from systematic reviews that combined results statistically.

\section{Health Equity Impact Assessment}

We used the Ontario Ministry of Health and Long-Term Care Health Equity Impact Assessment (HEIA) tool (available at: http://www.health.gov.on.ca/en/pro/programs/heia/) to assess likely intended and unintended effects in priority populations (completed template available from the authors on request). To make these judgments about unintended effects and mitigation strategies, two from our team of researchers (JP, VW) reviewed data on Internet access and also considered known barriers and facilitators for specific populations based on our expertise in reviewing effects of interventions on health equity. $^{21,27}$ The HEIA tool is intended to help identify how a program, policy or other initiative will impact different groups of the population, the primary focus being barriers in access to programs. ${ }^{28}$ We used data on access and use of social media platforms from the Canadian Internet Use Survey to measure access to Internet and Internet use behaviour (survey results available upon request).

\section{Results}

\section{Results of search}

The search strategy identified 4103 records after duplicates were removed. After screening abstracts and titles, 3957 records were excluded and 146 articles were retrieved for full-text screening. We excluded
135 systematic reviews because the interventions used one-way communication (e.g. one-way reminders for appointments) or used the Internet for treatment (e.g. cognitive-based therapy by Internet) or for one-way education or information messages, with no interaction among users or user-generated content (see Figure 1). A table of excluded studies is available upon request.

We included 11 systematic reviews in this overview (see Table 2 for the characteristics of these studies).

\section{Description of reviews}

Most of the systematic reviews focussed on online discussion boards or similar strategies, either as stand-alone interventions or in combination with other interventions. Only three reviews included studies that used the most common social media tools, Facebook ( $n=19$ unique studies) and Twitter ( $\mathrm{n}=9$ unique studies).$^{8,9,30}$ Although they were included in the search criteria, none of the interventions in the systematic reviews were defined as mobile phone applications.

In the older studies included in the reviews, most of the discussion boards were "closed" spaces, where only study participants could access the discussion board (i.e. there was no interaction with external people or communities). For example, in the Chang et al. review ${ }^{9}$ of online weight management using social media, $85 \%$ of the studies used a closed, researcher-developed website.

In the studies where social media was part of a complex intervention, it focussed on maintaining engagement with the other components of the intervention, to provide feedback on the intervention and a space to formulate questions and get answers. For example, in the Williams et al. review, ${ }^{30}$ all of the 16 studies had social media as a component of a complex intervention where other components included websites with fact sheets and information or therapist-led email interactions.

In the 11 systematic reviews included, the populations were diverse in terms of age (children, youth, adults and older people), disease conditions (e.g. cancer, cardiovascular, asthma, depression, eating disorders) and sex/gender (i.e. no exclusion criteria related to sex/gender). One large systematic review of 98 studies of social media interventions for a broad range of health promotion activities included diverse populations in terms of ethnicity, socioeconomic status, age and education. ${ }^{8}$

\section{Effects of social media interventions}

We could not combine results to generate pooled meta-analyses. The results of each review are summarized in Table 3 . We have reported effect sizes and confidence intervals when these have been available.

Of the 11 included reviews, seven reported mixed effects on health outcomes and health behaviours (details below). The remaining four reported benefits such as satisfaction, finding information and social support. $^{8,31-33}$

\section{Knowledge}

The review by Newton \& Ciliska $^{12}$ (AMSTAR score 7) reported on knowledge outcomes and found "a statistically significant increase in knowledge" about healthy lifestyle attitudes and behaviours.

\section{Weight loss}

A review by Williams et al. $^{30}$ (AMSTAR score 9) pooled nine studies of social media interventions aimed at weight loss and found no difference between social media and control groups (weight $0.00 \mathrm{~kg}$; $95 \%$ CI: -0.19 to $0.19 \mathrm{~kg}$ ). However, another review, by Chang et al. ${ }^{9}$ (AMSTAR score 5) included five of the same studies as Williams et al. ${ }^{30}$ and reported that nine studies showed greater weight loss with the social media intervention than in the control group, but four studies showed no effect and two showed less weight loss among the social media group than those receiving face-to-face interventions. A third review, by Eysenbach et al. $^{34}$ (AMSTAR score 6), found "mixed but mostly nonsignificant" effects of social media on weight outcomes.

Behaviour change: physical activity

The review by Chang et al. ${ }^{9}$ (AMSTAR score 5) reported that two studies showed 
FIGURE 1

PRISMA 2009 flow diagram ${ }^{29}$ showing the selection process to identify relevant systematic reviews

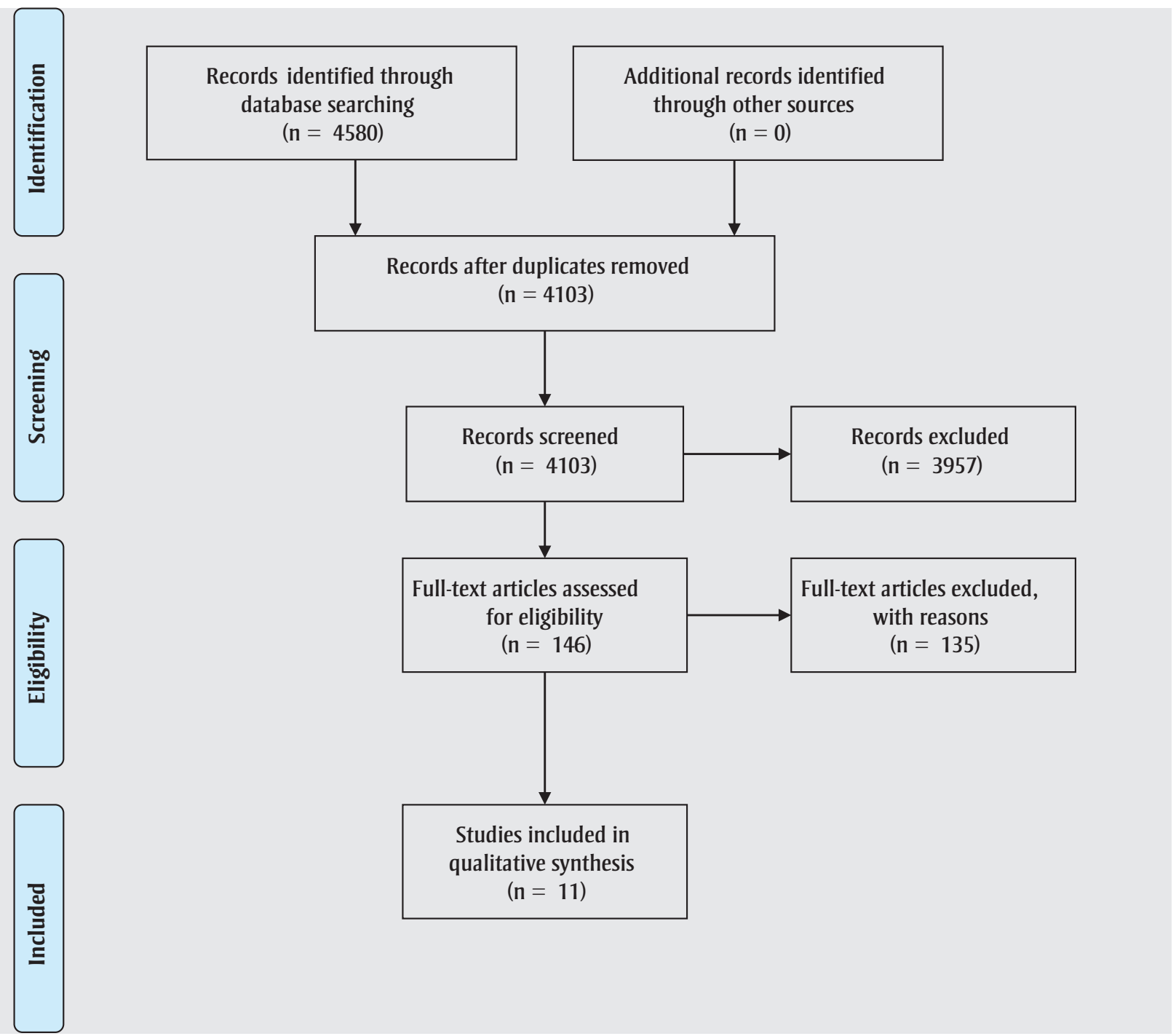

an increase in self-reported physical activity and three studies showed no difference in physical activity. Williams et al. ${ }^{30}$ (AMSTAR score 9) conducted a metaanalysis of 12 studies and reported an increase in physical activity among the social media group (SMD 0.13; $95 \% \mathrm{CI}$ : -0.04 to 0.30$)$.

\section{Behaviour change: diet}

A review by Medina et al. ${ }^{32}$ (AMSTAR score 3) examined online social media platforms for people with cardiovascular disease and described improved diet and quality of life among those using these platforms. The review by Chang et al. ${ }^{9}$ (AMSTAR score 5) included one study that found "no statistically significant differences" in body mass index
(BMI), waist-to-hip ratio, blood pressure or cholesterol following a dietary intervention.

\section{Behaviour change: smoking}

The review by Eysenbach et al. ${ }^{34}$ (AMSTAR score 6) reported a higher rate of smoking cessation in a peer-to-peer online support group compared to a group without peerto-peer support. However the rates in the peer-to-peer online plus psychoeducational intervention were similar to the group receiving a psychoeducational intervention alone.

\section{Health care utilization}

One study in the review by Medina et al. ${ }^{32}$ (AMSTAR score 3) reported that the number of medical visits "decreased mildly" following an online support group intervention using a moderator. However, this did not persist in the second phase once the moderator was removed. ${ }^{32}$ The Eysenbach et al. ${ }^{34}$ review (AMSTAR score 6) included three studies that reported on health care utilization. One study within this review reported fewer calls to doctors following the social media intervention while another found an increase in calls to providers (effect sizes not provided but authors report $p<.05$ ).

\section{Mental health outcomes}

The Lai et al. ${ }^{31}$ review (AMSTAR score 6), which included four studies with social media components, found that Internetbased cognitive behaviour therapy with social media interventions (online message board or support groups) reduced 
TABLE 2

Characteristics of included studies-interventions, populations and outcomes

\begin{tabular}{|c|c|c|c|c|c|c|c|c|}
\hline Citation & Population & Intervention & Eligibility criteria & $\begin{array}{c}\text { Target } \\
\text { outcome } \\
\text { (length of } \\
\text { follow-up) }\end{array}$ & $\begin{array}{l}\text { Number of } \\
\text { studies } \\
\text { (number of } \\
\text { studies with } \\
\text { social media } \\
\text { components) }\end{array}$ & $\begin{array}{l}\text { Types of } \\
\text { eligible } \\
\text { studies }\end{array}$ & $\begin{array}{c}\text { Country } \\
\text { (number } \\
\text { of } \\
\text { studies) }\end{array}$ & $\begin{array}{c}\text { AMSTAR } \\
\text { score }\end{array}$ \\
\hline $\begin{array}{l}\text { Chang et al., } \\
2012^{9}\end{array}$ & $\begin{array}{l}\text { Individuals of all } \\
\text { ages using social } \\
\text { media for weight } \\
\text { management }\end{array}$ & $\begin{array}{l}\text { Most interventions } \\
\text { were message boards } \\
\text { or chat rooms } \\
\text { designed by the } \\
\text { researchers; } 2 \text { studies } \\
\text { used Facebook and } \\
\text { one used Twitter }\end{array}$ & $\begin{array}{l}\text { Report weight-related } \\
\text { outcomes, include a social } \\
\text { media component (web- } \\
\text { based application that } \\
\text { allow interaction in a } \\
\text { virtual community) }\end{array}$ & $\begin{array}{l}\text { Weight } \\
\text { management } \\
\text { ( } 6 \text { to } 12 \\
\text { months) }\end{array}$ & $20(20)$ & RCT & $\begin{array}{l}\text { USA } \\
(n=14), \\
\text { Australia } \\
(n=3), \\
\text { Canada } \\
(n=2), \\
\text { UK } \\
(n=1)\end{array}$ & 5 \\
\hline $\begin{array}{l}\text { Eysenbach } \\
\text { et al., } 2004^{34}\end{array}$ & $\begin{array}{l}\text { Various e.g. } \\
\text { pregnant women, } \\
\text { caregivers of } \\
\text { people with } \\
\text { Alzheimer } \\
\text { disease, adults } \\
\text { with diabetes, } \\
\text { people with AIDS, } \\
\text { young single } \\
\text { mothers, adult } \\
\text { smokers, etc. }\end{array}$ & $\begin{array}{l}\text { Virtual communities, } \\
\text { web-based discussion } \\
\text { forums, chat rooms, } \\
\text { mailing list, voice } \\
\text { bulletin board that } \\
\text { involved peer-to-peer } \\
\text { interaction }\end{array}$ & $\begin{array}{l}\text { Interventions needed to } \\
\text { be a virtual community or } \\
\text { have a virtual community } \\
\text { component (a group of } \\
\text { individuals who interact } \\
\text { publicly through a } \\
\text { computer communication } \\
\text { network or other } \\
\text { computer-based tool); } \\
\text { focus broadly on health or } \\
\text { health care issues; have } \\
\text { outcomes that relate to } \\
\text { knowledge, health, } \\
\text { psychological or social } \\
\text { outcomes, health service } \\
\text { use include a control } \\
\text { group }\end{array}$ & $\begin{array}{l}\text { Health and } \\
\text { social } \\
\text { outcomes } \\
\text { (10 weeks to } \\
12 \text { months) }\end{array}$ & $38(38)$ & $\mathrm{RCT}, \mathrm{CBA}$ & $\begin{array}{l}\text { Not } \\
\text { reported }\end{array}$ & 6 \\
\hline $\begin{array}{l}\text { Griffiths, } \\
2009^{39}\end{array}$ & $\begin{array}{l}\text { Adults and } \\
\text { adolescents; some } \\
\text { participants with } \\
\text { cancer, } \\
\text { depression, } \\
\text { chronic illness, } \\
\text { HIV; caregivers }\end{array}$ & $\begin{array}{l}\text { Internet support } \\
\text { groups (e.g. bulletin } \\
\text { boards, chatrooms or } \\
\text { mailing lists, either } \\
\text { alone or in } \\
\text { combination) }\end{array}$ & $\begin{array}{l}\text { Interventions included an } \\
\text { online peer-to-peer } \\
\text { support group; had a } \\
\text { depression outcome; } \\
\text { involved a unipolar } \\
\text { depression Internet } \\
\text { support group }\end{array}$ & $\begin{array}{l}\text { Depression } \\
\text { (12 weeks to } \\
12 \text { months) }\end{array}$ & $28(10)$ & $\begin{array}{l}\text { RCT, pre-post, } \\
\text { case series, } \\
\text { cross- } \\
\text { sectional, ITS }\end{array}$ & $\begin{array}{l}\text { USA } \\
(\mathrm{n}=23) \\
\text { Europe } \\
(\mathrm{n}=4) \\
\text { Australia } \\
(\mathrm{n}=1)\end{array}$ & 9 \\
\hline $\begin{array}{l}\text { Lai et al., } \\
2014^{31}\end{array}$ & Mostly adults & $\begin{array}{l}\text { Web-based suicide } \\
\text { prevention- including } \\
\text { any intervention } \\
\text { delivered by Internet } \\
\text { (e.g. cognitive } \\
\text { behavioural therapy, } \\
\text { online support } \\
\text { groups, message } \\
\text { board) }\end{array}$ & $\begin{array}{l}\text { Web-based suicide } \\
\text { prevention strategies with } \\
\text { a discussion of the } \\
\text { efficacy, benefits or } \\
\text { challenges of the } \\
\text { intervention }\end{array}$ & $\begin{array}{l}\text { Suicidal } \\
\text { ideation } \\
\text { ( } 6 \text { weeks to } \\
12 \text { months) }\end{array}$ & $15(4)$ & $\begin{array}{l}\text { RCTs, pre-post } \\
\text { case series, } \\
\text { cohort, cross- } \\
\text { sectional, } \\
\text { qualitative, } \\
\text { descriptive } \\
\text { reports }\end{array}$ & USA & 6 \\
\hline $\begin{array}{l}\text { Medina et al., } \\
2013^{32}\end{array}$ & $\begin{array}{l}\text { Adults with } \\
\text { cardiovascular } \\
\text { disease }\end{array}$ & $\begin{array}{l}\text { Online support group } \\
\text { for people with } \\
\text { cardiovascular disease } \\
\text { (both moderated and } \\
\text { unmoderated groups } \\
\text { included) }\end{array}$ & $\begin{array}{l}\text { Online support groups, } \\
\text { patients with } \\
\text { cardiovascular disease }\end{array}$ & $\begin{array}{l}\text { Benefits and } \\
\text { negative } \\
\text { outcomes } \\
\text { (1 study: } \\
9 \text { months; } \\
\text { others: not } \\
\text { reported) }\end{array}$ & $4(4)$ & CBA, cohort & $\begin{array}{l}\text { USA } \\
(\mathrm{n}=3) \\
\text { UK } \\
(\mathrm{n}=1)\end{array}$ & 3 \\
\hline
\end{tabular}


TABLE 2 (continued)

Characteristics of included studies-interventions, populations and outcomes

\begin{tabular}{|c|c|c|c|c|c|c|c|c|}
\hline Citation & Population & Intervention & Eligibility criteria & $\begin{array}{l}\text { Target } \\
\text { outcome } \\
\text { (length of } \\
\text { follow-up) }\end{array}$ & $\begin{array}{l}\text { Number of } \\
\text { studies } \\
\text { (number of } \\
\text { studies with } \\
\text { social media } \\
\text { components) }\end{array}$ & $\begin{array}{l}\text { Types of } \\
\text { eligible } \\
\text { studies }\end{array}$ & $\begin{array}{c}\text { Country } \\
\text { (number } \\
\text { of } \\
\text { studies) }\end{array}$ & $\begin{array}{c}\text { AMSTAR } \\
\text { score }\end{array}$ \\
\hline $\begin{array}{l}\text { Moorhead } \\
\text { et al., } 2013^{8}\end{array}$ & $\begin{array}{l}\text { Mixed, from } \\
\text { schoolchildren to } \\
\text { older adults, } \\
\text { various education, } \\
\text { socioeconomic } \\
\text { status, ethnicity }\end{array}$ & $\begin{array}{l}\text { Communication } \\
\text { between the general } \\
\text { public and/or patients } \\
\text { and/or health } \\
\text { professionals about } \\
\text { health issues using } \\
\text { social media (Facebook } \\
(\mathrm{n}=13) \text {, blogs } \\
(\mathrm{n}=13) \text {, Twitter } \\
(\mathrm{n}=8) \text {, YouTube } \\
(\mathrm{n}=7) \text {, myspace } \\
(\mathrm{n}=5) \text {, Patients } \\
\text { LikeMe }(\mathrm{n}=4) \text { and } \\
\text { other types of social } \\
\text { media }(\mathrm{n}=53))\end{array}$ & $\begin{array}{l}\text { Interventions needed to } \\
\text { focus primarily on all } \\
\text { communication } \\
\text { interactions within and } \\
\text { between the general } \\
\text { public and/or patients } \\
\text { and/or health } \\
\text { professionals about health } \\
\text { issues using social media, } \\
\text { including uses, benefits or } \\
\text { limitations of social media } \\
\text { for health communication }\end{array}$ & $\begin{array}{l}\text { Use, benefits } \\
\text { or limitations } \\
\text { of social } \\
\text { media(not } \\
\text { reported) }\end{array}$ & $98(98)$ & $\begin{array}{l}\text { RCTs, network } \\
\text { analyses, cross- } \\
\text { sectional, } \\
\text { qualitative, } \\
\text { descriptive } \\
\text { reports, } \\
\text { secondary data } \\
\text { analyses }\end{array}$ & $\begin{array}{l}\text { Mostly } \\
\text { high } \\
\text { income } \\
\text { (not } \\
\text { reported) }\end{array}$ & 5 \\
\hline $\begin{array}{l}\text { Nef et al., } \\
2013^{33}\end{array}$ & $\begin{array}{l}\text { Older than } 55 \\
\text { years }\end{array}$ & $\begin{array}{l}\text { Social networking } \\
\text { sites }\end{array}$ & $\begin{array}{l}\text { Needed to include social } \\
\text { media intervention for } \\
\text { people } 55 \text { years and older }\end{array}$ & $\begin{array}{l}\text { Acceptance, } \\
\text { harms (mental } \\
\text { health) } \\
\text { ( } 2 \text { studies } \\
\text { reported } \\
\text { follow-up: } \\
7 \text { weeks and } \\
21 \text { weeks) }\end{array}$ & $18(18)$ & CBA, cohort & $\begin{array}{l}\text { High } \\
\text { income; } \\
\text { not } \\
\text { specified } \\
\text { for each } \\
\text { study }\end{array}$ & 3 \\
\hline $\begin{array}{l}\text { Newton \& } \\
\text { Ciliska, } \\
2006^{12}\end{array}$ & $\begin{array}{l}\text { Grade } 10 \text { and } \\
\text { undergraduate } \\
\text { students. Median } \\
\text { age range } 15-20 \\
\text { years }\end{array}$ & $\begin{array}{l}\text { All studies used the } \\
\text { program "student } \\
\text { bodies," which } \\
\text { includes } \\
\text { psychoeducational } \\
\text { readings and } \\
\text { reflection, Internet- } \\
\text { based body image } \\
\text { journal, } \\
\text { asynchronous online } \\
\text { discussion group }\end{array}$ & $\begin{array}{l}\text { Interventions evaluating } \\
\text { Internet-based prevention } \\
\text { programs (guided or non- } \\
\text { guided, synchronous or } \\
\text { asynchronous, individual } \\
\text { or group format) }\end{array}$ & $\begin{array}{l}\text { Disordered } \\
\text { eating } \\
\text { attitudes/ } \\
\text { behaviours } \\
\text { (10 to } \\
24 \text { weeks) }\end{array}$ & $5(5)$ & $\mathrm{RCT}, \mathrm{CBA}$ & $\begin{array}{l}\text { US (all } \\
\text { California) }\end{array}$ & 7 \\
\hline $\begin{array}{l}\text { Nieto et al., } \\
2008^{40}\end{array}$ & $\begin{array}{l}\text { Adults (median } \\
\text { ages } 45.5 \text { and } 47 \text { ) }\end{array}$ & $\begin{array}{l}\text { Internet support } \\
\text { groups (e.g. email } \\
\text { discussion lists) }\end{array}$ & $\begin{array}{l}\text { Studies that evaluated the } \\
\text { effectiveness of any } \\
\text { treatment for patients } \\
\text { with chronic pain using } \\
\text { new information and } \\
\text { communication } \\
\text { technologies }\end{array}$ & $\begin{array}{l}\text { Pain } \\
\text { (3 to } 12 \\
\text { months) }\end{array}$ & $7(2)$ & & $\begin{array}{l}\text { USA } \\
(\mathrm{n}=1) \\
1 \text { not } \\
\text { reported }\end{array}$ & 3 \\
\hline $\begin{array}{l}\text { Williams } \\
\text { et al., } 2014^{30}\end{array}$ & $\begin{array}{l}16 \text { studies in } \\
\text { adults, } 6 \text { included } \\
\text { children and } \\
\text { youth. } 70 \% \\
\text { female in } 10 \\
\text { studies with both } \\
\text { sexes, } 6 \text { studies of } \\
\text { women only }\end{array}$ & $\begin{array}{l}\text { Online discussion } \\
\text { boards allowing for } \\
\text { the exchange of user- } \\
\text { generated content }\end{array}$ & $\begin{array}{l}\text { Social media interventions } \\
\text { promoting healthy diet } \\
\text { and exercise in the general } \\
\text { population }\end{array}$ & $\begin{array}{l}\text { Physical } \\
\text { activity and } \\
\text { diet behaviour } \\
\text { (10 weeks to } \\
24 \text { months) }\end{array}$ & $16(16)$ & RCTs & $\begin{array}{l}\text { USA } \\
(\mathrm{n}=10), \\
\text { Australia } \\
(\mathrm{n}=3) \\
\text { and } 3 \text { in } \\
\text { other } \\
\text { countries }\end{array}$ & 9 \\
\hline
\end{tabular}

Abbreviations: CBA, controlled before-after study; ITS, interrupted time series; RCT, randomized controlled trial.

suicidal ideation (effect sizes ranged from $d=0.04-0.45)$.

The review by Hong et al. ${ }^{35}$ (AMSTAR score 3) studied the effects of Internetbased groups on depression among cancer survivors, principally breast cancer survivors. Participants valued the Internetbased tools positively, and most of the studies found a positive effect of social media groups. However, for the few interventions that were compared to another type of program (e.g. a face-to-face program), the social media intervention had similar results or was less effective (e.g. one study reported higher depression rates among the social media group than the face-to-face group). 
TABLE 3

Results of included systematic reviews

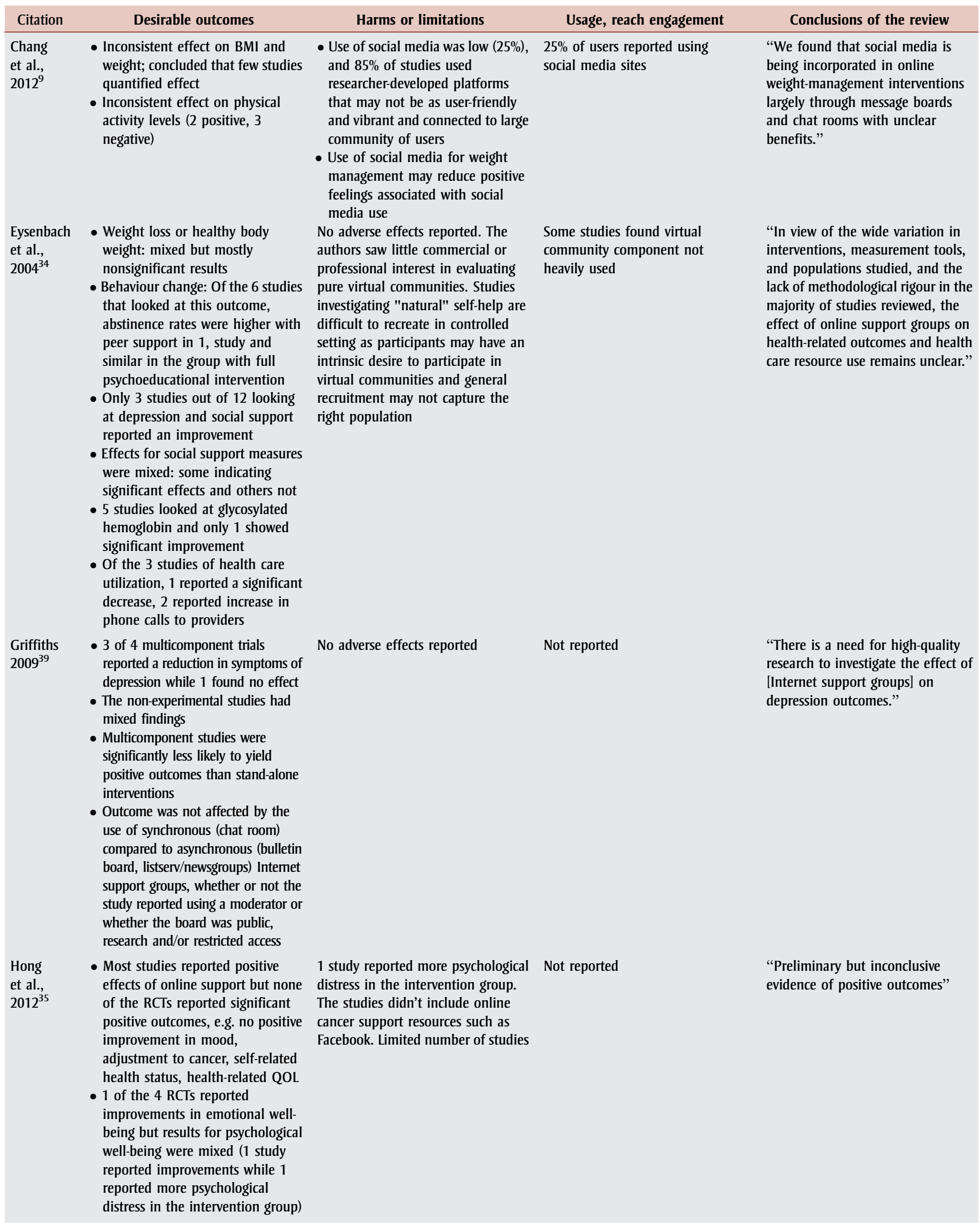

Continued on the following page 
TABLE 3 (continued)

Results of included systematic reviews

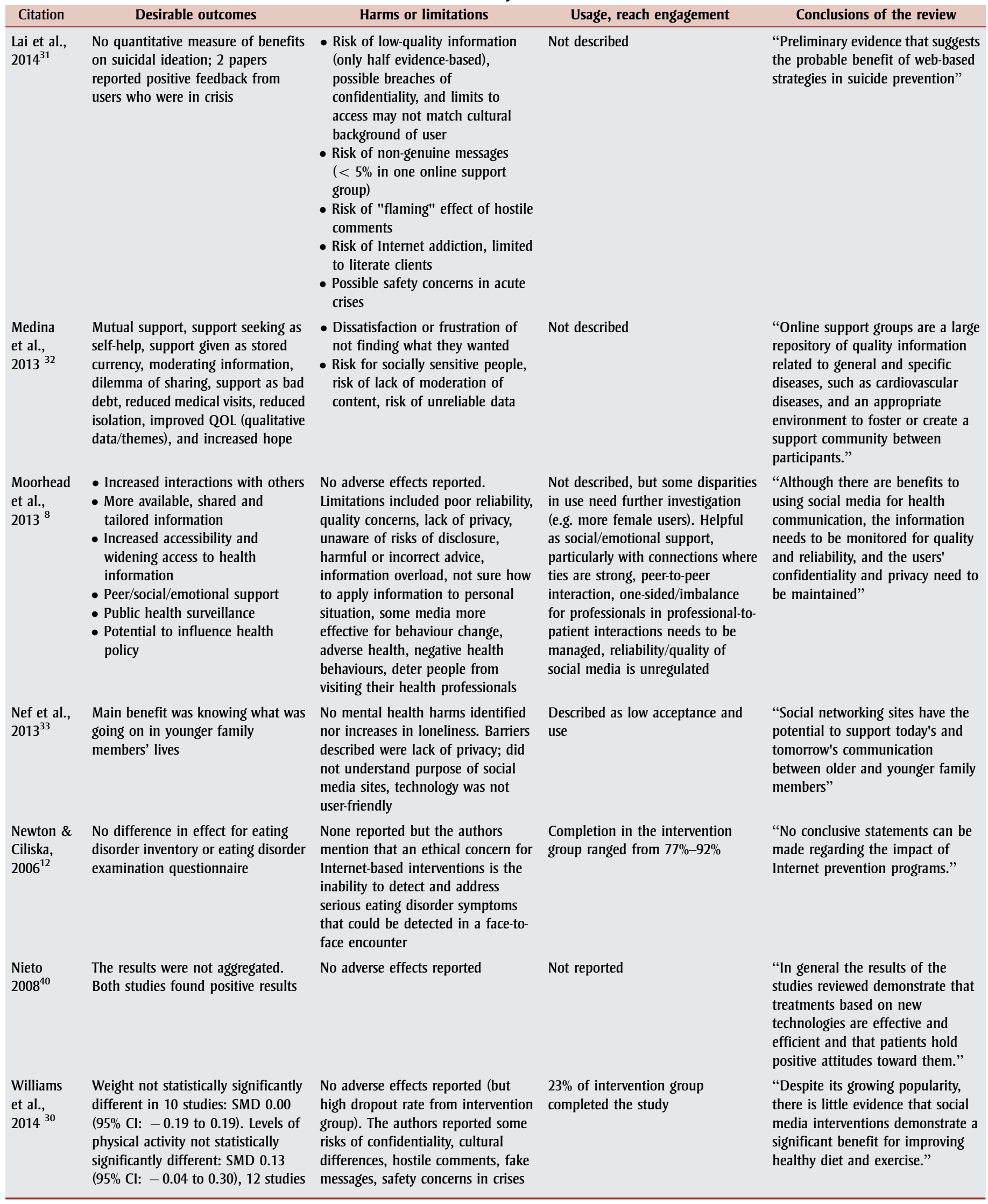

Abbreviations: BMI, body mass index; $\mathrm{CBA}$, controlled before-after study; Cl, confidence interval; QOL, quality of life; RCT, randomized controlled trial; SMD, standardized mean difference. 


\section{Potential harms}

Harms or adverse effects were not quantified in any of the systematic reviews. Most of the studies included in the reviews reported dropout rates of $20 \%$ or more. ${ }^{9,30}$ The reasons for these attrition rates were not explored in the primary studies.

The reviews described possible harmful effects such as missed symptoms, concerns about quality of care, increased stress, dissatisfaction, privacy concerns and loneliness. Newton \& Ciliska ${ }^{12}$ raised the ethical concern that Internet-based interventions may miss serious symptoms that would have been detected in face-to-face encounters. Lai et $\mathrm{al}^{31}$ raised concerns about the quality of information provided for users of social media, a lack of confidentiality and the inability of counsellors and moderators to react on a timely manner to crises. In a qualitative analysis, Medina et al. ${ }^{32}$ described participants' frustration or dissatisfaction due to misdiagnoses or lack of information or support as a limitation of social media. Nef et al. $^{33}$ (AMSTAR score 3) did not find any reported harms on mental health or loneliness, but described concerns among older adults about privacy and inappropriate content. Moorhead et al. ${ }^{8}$ (98 included studies, AMSTAR score 5) mentioned poor reliability and quality of the health care information and lack of privacy as possible harms. None of the reviews reported an increase in negative or unhealthy behaviours.

\section{What evidence was available on health equity?}

The reviews we included did not present disaggregated analyses across characteristics associated with disadvantage. Three reviews suggested that results may be applicable to diverse populations, based on their findings, as follows:

- no difference between youth and adults in effectiveness of social media on healthy diets, behaviours and physical activity; ${ }^{30}$

- participants with lower baseline social support or social capital were more likely to use social media; ${ }^{9}$ and

- social media users were disproportionately from lower-income households. ${ }^{8}$

Nef et al. ${ }^{33}$ assessed qualitative studies of Internet use by older adults (people $\geq 55$ years) and reported that the Internet helped this population maintain connections with family and friends, and that there was no evidence of increased loneliness or harm as a result of Internet use. ${ }^{33}$ In their review, Lai et al. ${ }^{31}$ reported that the anonymous nature of Internet-based activities could, in fact, help promote health-seeking behaviour in harder-toreach at-risk groups. Hong et al. ${ }^{35}$ reported that social media was helpful in reaching rural participants (though only one study included rural populations). Two reviews mentioned that literacy levels could affect the effectiveness of the intervention. ${ }^{31,35}$ Only Moorhead et al. ${ }^{8}$ mentioned that the social media materials could be adapted for different literacy levels.

\section{Which design elements promote health equity?}

Using the HEIA tool developed by the Ontario Ministry of Health and Long-term Care, we described the possible concerns for twelve populations, such as ethnoracial communities, age-related groups, sex/gender and physical disability and, where studies in the systematic reviews made reference to potential mitigation strategies, their proposed strategies.

The main concern common to several populations is the possibility of limited access to the Internet (e.g. homeless people or low-income older adults). To mitigate inequities, health promotion using social media may require providing access to the Internet and computers/mobile devices.

None of the reviews mentioned additional resources that may be needed for the behaviour changes promoted by the social media interventions, such as availability of walking paths, access to fitness facilities, affordability of co-interventions (such as nicotine patches for smoking cessation), access to affordable food and access to health care. However, these determinants and facilitators to behaviour changes should be considered in the underlying program theory and the development of any social media intervention. ${ }^{36}$

Since newer social media interventions are designed to build on individuals' existing social networks, people with few social networks may be at a disadvantage (e.g. low-income seniors have few ties other than their grandchildren ${ }^{33}$ ). However, Chang et al. ${ }^{9}$ showed that people with few social networks tended to use social media more, suggesting they may benefit from these interventions.

Several reviews raised the acceptability of social media interventions as a concern. Acceptability may relate to cultural acceptability and norms (such as with one study designed for a Hebrew-speaking audience $^{31}$ ) or to population-specific preferences (e.g. one review of older adults reported unfamiliarity with Facebook ${ }^{33}$ ). Several reviews proposed that user testing and acceptability testing would be useful to increase the likelihood that social media interventions will be taken up by the target populations.

The reviews reported that privacy concerns and confidentiality may be an issue for certain populations such as older adults and may affect the use of social media interventions. Quality control on social media sites, such as that provided by a moderator, might help reduce privacy concerns and encourage use. ${ }^{8}$

Some populations may be particularly sensitive to hostile or misleading comments. If so, these interventions may be designed to allow a moderator to limit access to the social media group to reduce the risk of inappropriate use.

\section{Areas for further research}

We did not find any examples of systematic reviews that focussed on using smartphone or tablet applications and social media for health promotion, possibly because smartphone applications have been only recently developed and tested. User-friendly design was described as an area for future development.

An area for further research is the use of well-known social media platforms (e.g. Facebook and Twitter) for health promotion interventions. Only 28 studies (included in 4 reviews) used well-known social media sites as the platform for the intervention; 
the remainder used platforms developed by the researchers. These closed platforms did not take advantage of participants' existing social networks, but rather aimed at developing connections between people in the same health promotion/support research program so they could share experiences.

\section{Discussion}

The reviews in this overview suggest a potential to improve health outcomes and health-promoting behaviours in the targeted populations. However, increasing health inequity was also a risk because of issues to do with access to, acceptability of and the unmonitored quality of social media.

Future research should aim to identify which social media interventions are effective and describe all aspects of the interventions, including how they are implemented and utilized, using explicit criteria such as the TIDIER (Template for Intervention Description and Replication) checklist. ${ }^{37}$ Research should also explicitly document any increased negative behaviours, stigmatization or exacerbation of existing health inequities if some populations are excluded.

Interventions that use the more commonly known social media sites may experience higher use and acceptability rates because they take advantage of existing social networks. Future research should assess these platforms.

We did not find disaggregated analyses across characteristics associated with disadvantage. However, some targeted studies reported that social media interventions were effective in youth and older adults, ${ }^{30,33}$ in groups with lower socioeconomic status, ${ }^{8}$ in different ethnicities, ${ }^{31}$ and among rural participants. ${ }^{35}$ Several reviews proposed that social media could help engage harder-to-reach populations and could be designed to overcome literacy and education gaps, provided there was access to technology. However, there was very little evidence available for these populations in the primary studies or the systematic reviews. Future systematic reviews and primary studies should collect and analyze the effect of the intervention by different population groups.

There is a need for qualitative research on the role of theory-based program design and evaluation, use of multiple components, user-centred design, and measurement of the implementation process (including use, interaction and satisfaction). When planning a social media intervention, the target population's baseline use of social media should be considered. Social media has the potential to reach harder-to-reach populations, Internet access being widely available across Canada.

\section{Strengths and limitations}

A strength of this overview is that we took a broad approach to allow us to examine the effects of various social media interventions across a wide range of health conditions. Despite our broad inclusion criteria, we only found reviews that compared minimal intervention conditions (e.g. access to noninteractive or limited versions of study websites). ${ }^{30}$ We used rapid review methods to respond to a need identified by our knowledge user. We were limited by the quality of reporting in the systematic reviews: 5 of the 11 reviews scored 5 or less out of a possible 11 on the AMSTAR tool for quality because of limitations in the search strategy, eligibility criteria and documentation of results. In other words, almost half of the systematic reviews were of low quality. Only one review reported on effect sizes with confidence intervals; others provided a narrative summary or reported only $p$ values. This limited our ability to assess the size of effects and confidence in the estimates.

The systematic reviews did not consistently monitor or report use of the social media interventions. Only four reported on participant use of the intervention and all reported low use. ${ }^{8,9,30,34}$ More than $20 \%$ of participants dropped out of the studies, and one review reported that less than $25 \%$ of the participants used the social media on offer as part of the studies. ${ }^{9}$ As a result, we cannot determine whether the lack of effect or the mixed effects were due to lack of use by participants or lack of effectiveness of the social media. Mixed effects may also be due to factors such as differences in populations, intervention design and implementation and/or concomitant interventions.

The HEIA tool provides a structured approach to assessing intended and unintended effects that help identify mitigation strategies. Ideally, however, this tool is used to inform the planning and development of interventions, and consultation and engagement with affected communities is essential. ${ }^{38}$

Finally, we used a rapid overview approach and therefore screening of the reviews identified by our search, data extraction and quality assessment was done by one author. We do not feel that this limitation affects the results of our overview.

\section{Conclusion}

Based on this overview of systematic reviews, effects of social media interventions are mixed or even small. There is insufficient evidence of the design and implementation features (e.g. intensity and duration of interventions) that could lead to improved effects. More research is needed on social media that engages with existing social networks (rather than research-only platforms), acceptability and use of social media, and assessment of both desirable and undesirable effects.

\section{Acknowledgements}

Funding for this project was provided by the Public Health Agency of Canada.

\section{References}

1. Neiger BL, Thackeray R, Van Wagenen SA, Hanson CL, West JH, Barnes MD, et al. Use of social media in health promotion: purposes, key performance indicators, and evaluation metrics. Health Promot Pract. 2012;13(2):159-64.

2. Public Health Agency of Canada. Public Health PHAC [Internet]. @PHAC_GC; 2015 [cited 2016 Jan 17]. Available from: https:// twitter.com/phac_gc 
3. Public Health Agency of Canada. Public Health Agency of Canada. Government Organisation [Internet]. Menlo Park (CA): Facebook; 2015 [cited 2016 Jan 17]. Available from: https://www.facebook.com/PublicHealth-Agency-of-Canada-10860597051/timeline/

4. Davies J, Mai D, Williams M, Dhaliwal M, Brankley L, McColl K; Social Media \& Technology Project Team. Environmental scan of social media at Ontario Public Health Units: analyzing the effectiveness of social media planning, implementation and evaluation at Health Units in Ontario. Guelph (ON): Wellington-Dufferin-Guelph Public Health; 2013.

5. Lenhart A, Purcell K, Smitth A, Zickuhr K. Social media and young adults [Internet]. Washington (DC): Pew Research Center; 2010 Feb 3 [cited 2015 Jan 14]. Available from: http://www.pewinternet.org/2010/ 02/03/social-media-and-young-adults/

6. Statistics Canada. Table 358-0153. Canadian Internet use survey, Internet use, by age group, Internet activity, sex, level of education and household income, occasional (percent) [Internet]. Ottawa (ON): CANSIM database; [modified 2013 Oct 28; cited 2014 Nov 04]. Available from: http://www5. statcan.gc.ca/cansim/a26?id $=3580153 \&$ retrLang $=$ eng\&lang $=$ eng

7. Kietzmann JH, Hermkens K, McCarthy IP, Silvestre BS. Social media? Get serious! Understanding the functional building blocks of social media. Bus Horizons.2011;54(3):241-51.

8. Moorhead SA, Hazlett DE, Harrison L, Carroll JK, Irwin A, Hoving C. A new dimension of health care: systematic review of the uses, benefits, and limitations of social media for health communication. J Med Internet Res. 2013;15(4):e85. DOI: 10.2196/ jmir.1933.

9. Chang T, Chopra V, Zhang C, Woolford SJ. The role of social media in online weight management: systematic review. J Med Internet Res. 2013;15(11):e262. DOI: 10.2196/jmir.2852.

10. Bailey JV, Murray E, Rait G, et al. Computerbased interventions for sexual health promotion: systematic review and meta-analyses. Int J STD AIDS. 2012;23(6):408-13. DOI: 10.1258/ ijsa.2011.011221.
11. Murray E, Burns J, See TS, Lai R, Nazareth I. Interactive health communication applications for people with chronic disease. Cochrane Database Sys Rev. 2005(4): CD004274.

12. Newton MS, Ciliska D. Internet-based innovations for the prevention of eating disorders: a systematic review. Eat Disor. 2006;14(5):365-84.

13. Lorenc T, Petticrew M, Welch V, Tugwell P. What types of interventions generate inequalities? Evidence from systematic reviews. J Epidemiol Community Health. 2013;67(2): 190-3. DOI: 10.1136/jech-2012-201257.

14. Whitehead M. The concepts and principles of equity and health. Int J Health Services. 1992;22(3):429-45.

15. O’Connor D, Green S, Higgins JP. Chapter 5: Defining the review question and developing criteria for including studies. In: Higgins JP, Green S, editors. Cochrane handbook of systematic reviews of intervention: Cochrane Book Series Collaboration. Hoboken (NJ): John Wiley \& Sons; 2011.

16. Meglic M, Lamut A, Sinkovec A, Yared W. Chapter 3: Online social media as a tool to improve cancer prevention and health promotion. In: Boosting innovation and cooperation in European cancer control: key findings from the European Partnership for Action Against Cancer. Martin-Moreno JM, Albreht T, Rados Krnel S [Eds] Ljubljana: National Institute of Public Health of the Republic of Slovenia; Brussels: World Health Organization on behalf of the European Observatory on Health Systems and Policies. 2013. ISBN 978-961-6911-22-1.

17. Sterne J. Social media metrics: how to measure and optimize your marketing investment. Hoboken (NJ): John Wiley \& Sons; 2010.

18. Black AD, Car J, Pagliari C, et al. The impact of eHealth on the quality and safety of health care: a systematic overview. PLoS Med. 2011;8(1):e1000387. DOI: 10.1371/journal.pmed.1000387.

19. French B, Day E, Watkins C, et al. The challenges of implementing a telestroke network: a systematic review and case study. BMC Med Inform Decis Mak. 2013;13:125. DOI: 10.1186/1472-6947-13-125.
20. Jackson N, Waters E. Guidelines for systematic reviews in health promotion and public health taskforce. Criteria for the systematic review of health promotion and public health interventions. Health Promot Int. 2005;20(4):367-74

21. O'Neill J, Tabish H, Welch V, et al. Applying an equity lens to interventions: using PROGRESS ensures consideration of socially stratifying factors to illuminate inequities in health. J Clinical Epidemiology. 2014;67(1): 56-64. DOI: 10.1016/j.jclinepi.2013.08.005.

22. Khangura S, Konnyu K, Cushman R, Grimshaw J, Moher D. Evidence summaries: the evolution of a rapid review approach. Syst Rev. 2012;1:10. DOI: 10.1186/2046-4053-1-10.

23. Hartling L, Guise JM, Kato E, et al. EPC Methods: an exploration of methods and context for the production of rapid reviews. Research White Paper. Rockville (MD): Agency for Healthcare Research and Quality; 2015.

24. Montori VM, Wilczynski NL, Morgan D, Haynes RB. Optimal search strategies for retrieving systematic reviews from Medline: analytical survey. BMJ. 2005;330(7482):68.

25. Sampson M, McGowan J, Lefebvre C, Moher D, Grimshaw J. PRESS: peer review of electronic search strategies. Ottawa (ON): Canadian Agency for Drugs and Technologies in Health; 2008.

26. Shea BJ, Hamel C, Wells GA, et al. AMSTAR is a reliable and valid measurement tool to assess the methodological quality of systematic reviews. J Clin Epidemiol. 2009;62(10):1013-20. DOI: 10.1016/j.jclinepi.2008.10.009.

27. Welch V, Brand K, Kristjansson E, Smylie J, Wells G, Tugwell P. Systematic reviews need to consider applicability to disadvantaged populations: inter-rater agreement for a health equity plausibility algorithm. BMC Med Res Method. 2012;12:187. DOI: 10.1186/1471-228812-187.

28. Ministry of Health and Long-Term Care. Health rquity impact assessment (HEIA) workbook. Toronto (ON): Ontario Ministry of Health and Long-Term Care; 2012.

29. Moher D, Liberati A, Tetzlaff J, Altman DG. Preferred reporting items for systematic reviews and meta-analyses: the PRISMA statement. BMJ. 2009;339:b2535. 
30. Williams G, Hamm MP, Shulhan J, Vandermeer B, Hartling L. Social media interventions for diet and exercise behaviours: a systematic review and meta-analysis of randomised controlled trials. BMJ Open. 2014;4(2):e003926.

31. Lai MH, Maniam T, Chan LF, Ravindran AV. Caught in the web: a review of web-based suicide prevention. J Med Internet Res. 2014;16(1):e30. DOI: 10.2196/jmir.2973.

32. Medina EL, Loques Filho O, Mesquita CT. Health social networks as online life support groups for patients with cardiovascular diseases. Arq Bras Cardio. 2013;101(2):e39-45.

33. Nef T, Ganea RL, Muri RM, Mosimann UP. Social networking sites and older users - a systematic review. Int Psychogeriat. 2013; 25(7):1041-53.

34. Eysenbach G, Powell J, Englesakis M, Rizo C, Stern A. Health related virtual communities and electronic support groups: systematic review of the effects of online peer to peer interactions. BMJ. 2004;328(7449):1166.

35. Hong Y, Pena-Purcell NC, Ory MG. Outcomes of online support and resources for cancer survivors: a systematic literature review. Patient Educ Couns. 2012;86(3): 288-96. DOI: 10.1016/j.pec.2011.06.014.

36. Webb TL, Joseph J, Yardley L, Michie S. Using the internet to promote health behavior change: a systematic review and metaanalysis of the impact of theoretical basis, use of behavior change techniques, and mode of delivery on efficacy. J Med Internet Res. 2010;12(1):e4. DOI: 10.2196/jmir.1376.

37. Hoffmann TC, Glasziou PP, Boutron I, Milne R, Perera R, Moher D, et al. Better reporting of interventions: template for intervention description and replication (TIDieR) checklist and guide. BMJ. 2014;348:g1687. DOI: 10.1136/bmj.g1687.

38. Povall SL, Haigh FA, Abrahams D, ScottSamuel A. Health equity impact assessment. Health Promot Int. 2014;29(4):621-33. DOI: $10.1093 /$ heapro/dat012.

39. Griffiths KM, Calear AL, Banfield M. Systematic review on Internet support groups (ISGs) and depression (1): do ISGs reduce depressive symptoms?. J Med Internet Res. 2009;11(3):e40. DOI: 10.2196/jmir.1270.
40. Nieto R, Miro J, Huguet A. [New information and communication technologies in the treatment of chronic pain]. Rev Esp Anestesiol Reanim. 2008;55:426-33. 